\title{
Corporate governance and banking performance in the context of globalization
}

\author{
Ovidiu Andrei Cristian Buzoianu ${ }^{1 *}$, Petrut Cristian Vasilach $e^{2}$, Daniela Paduraru ${ }^{2}$, and Carol \\ Cristina Gombos ${ }^{2}$ \\ ${ }^{1}$ Bucharest University of Economic Studies, Assistant Prof., Bucharest, Romania \\ 2 Bucharest University of Economic Studies, Phd Student, Bucharest, Romania
}

\begin{abstract}
Research background: Research background is written after the literature review. For example, Pham Q et al. (2020), emphasizes the effects of corporate governance, which is in a continuous development in the context of globalization. On the other hand, there is an obvious link between the banking activity, which is intended to be as efficient and governing as possible, which is also highlighted in the work of Arora A (2018). The impact of corporate governance on banking performance is also presented. Carrying out banking activity in compliance with the principles of corporate governance, leads to shaping an efficient and conducive environment for both employees and the company itself. At the same time, the application of the concept aims at the overall management of the entities, which allows the common functioning of the internal components and the performance of internal control.

Purpose of the article: This paper aims to present the most important theoretical and practical aspects of the importance of corporate governance in banking performance. Corporate governance is currently receiving special attention, an argument being the numerous studies conducted and the growing interest that companies have in this concept

Methods: This paper starts from the hypothesis of the influence of globalization on corporate governance and banking performance. The article was based on the study of the literature and the identification of recent data on certain banking indicators. At the same time, values of banking dynamics at the level of the period 2016-2019 were analyzed and calculated. Last but not least, the method of comparison regarding the financial performances at the banking level and the profitability rate was used.

Findings \& Value added: Following these researches, it was found the link between globalization and the magnitude that corporate governance currently has, in close connection with banking performance, determines the corporate variety of activity worldwide or regionally. The main results were disseminated through the article and it adds value through the analysis
\end{abstract}

\footnotetext{
${ }^{*}$ Corresponding author: buzoianuovidiu@yahoo.com
} 
created at global and regional level (at European level) and the interpretation of statistical data related to banking.

Keywords: governance; corporations; globalisation; bank

JEL Classification: $F 65$; $G 24$

\section{Introduction}

The economic reality revolves more and more around the term "corporate governance", due to the upward trend of the private sector (Nastase et al, 2020). The multiple definitions of this concept are clues to the complexity and implications it has within organizations (Profiroiu et al, 2019).

Corporate governance is an "attempt to implement risk analysis, verification, evaluation, control systems, which contribute to the achievement of an efficient management for their operation" (Albu, 2013), is a system that allows the monitoring of the system. internal control in order to identify the risks, thus giving an extra security to the managers in view of the application of the strategies they have opted for (Burlacu et al, 2019).

Corporate governance also refers to "promoting fairness, transparency and accountability at the company level" (Arora, 2018), thus increasing investor confidence, making companies more attractive (Orzan et al., 2020).

Good corporate governance is not an end in itself, it is "a means of building trust and the integrity of the business market, which in turn is essential for companies that need access to equity for long-term investment" (Muhammad, 2019).

Although the implementation of corporate governance has proven beneficial for companies in developed countries, with the advent of codes of conduct, the changes have become more apparent (Pham, 2020).

These codes are in fact "a set of principles, standards and good governance practices, being optional and not mandatory" (Bunea M, 2013), but it should be noted that they indicate strategic directions and propose mechanisms for monitoring the activity of managers (Ionita et al., 2009).

Corporate governance has emerged as a result of resounding financial failures in the private sector and has resulted in a decline in investor confidence in the way companies are run (Verdun, 2018). This situation was also felt in the public domain (Bodislav et al., 2021). The main common reasons for these waves of scandals were: incompetence at the management level, poor distribution of responsibilities, non-compliance with procedures, ignoring risk management, neglect of internal auditors' recommendations, inefficiency of external auditors, greed of managers, etc. (Radulescu et al., 2020).

These cases of bankruptcy, to which are added the financial crises and the discrepancy between directors' compensation and the performance of organizations have shown that "the establishment of corporate governance is not just a means of survival" (Catană, 2015), but a direction of orientation of companies towards prosperity (Burlacu et al., 2018).

Corporate governance, "regardless of the governance model encountered, can be best observed in developed countries" (Chen, 2018), while in countries with economies in transition or in the least developed, it is completely lacking (Sarbu et al., 2021). The existence or non-existence of this concept directly influences both the development process of global strategies and the types of strategies that can be adopted "(Ciftci, 2019). Despite these impediments, some classifications can be used in the analysis of how countries interact (Coșneanu, 2013). 


\section{Methods}

This paper starts from the hypothesis of the influence of globalization on corporate governance and banking performance. The article was based on the study of the literature and the identification of recent data on certain banking indicators. At the same time, values of banking dynamics at the level of the period 2016-2019 were analyzed and calculated.

Last but not least, the method of comparison regarding the financial performances at the banking level and the profitability rate was used.

\section{Results and discussion}

\subsection{Corporate governance at the level of the European and Romanian Banking System}

Financial institutions have had to deal with the impact of the global crisis, both at European and global level (Dobroțeanu, 2013). This economic and financial crisis was a difficult hop to pass, negatively affecting the banking system. First, the profitability of banking institutions was affected, "with effects on all types of banking products and services offered to customers, supervision models and valuation methods known so far" (Bunea, 2018).

Corporate governance also includes the relationships between the different categories of people involved in banking (Haris, 2019), such as: management, board of directors, shareholders and employees. Credit institutions, compared to other financial institutions, are regulated and supervised much more closely, and corporate governance issues need to be shaped by their specific nature.

However, they failed to prevent excessive risk-taking, although it had internal control and risk management and audit committees (Donnelly, 2018). In Romania there are banking institutions belonging to multinational holding companies and credit institutions with domestic capital.

This is where the differences in approach start, ie depending on whether you belong to a European banking group or not. If the banks belong to a group, they take over the group's mechanisms, but they also take over Romanian regulations (Arniati, 2019)

Corporate governance practices and developments are constantly changing, so banks should work on structures, processes and practices that address their long-term needs (Cornel, 2019). The concept will be increasingly present in banks' strategies and must have as a fundamental objective the sustainable growth of the credit institution and provide transparency to all stakeholders.

As mentioned earlier, corporate governance encompasses all the systems and processes needed to lead and control an entity with the goal of increasing performance. In fact, it is about the efficiency of the risk management system, the role of management, the remuneration of members, the transparency and credibility of economic and financial situations. Basically, corporate governance would be the foundation of decision and control within a company, consisting of rules and procedures, responsibilities and responsibilities (E-Vahdati, 2019).

\subsection{Corporate governance and banking performance within the Romanian banking system}

In the analysis of the structure and dynamics of bank revenues and expenditures, it is intended that the volume of expenditures be lower than the volume of revenues, respectively the dynamics of expenditures be below the level of revenue dynamics or at most equal to the dynamics of revenues. 


\subsubsection{Analysis of the structure and dynamics of bank revenues and expenditures}

Table 1. Analysis of the dynamics of bank income and expenses.

\begin{tabular}{|c|c|c|c|c|c|}
\hline Elements & $\mathbf{2 0 1 7}$ & $\mathbf{2 0 1 8}$ & $\mathbf{2 0 1 9}$ & $\begin{array}{c}\text { Index } \\
\mathbf{2 0 1 8 / 2 0 1 7}\end{array}$ & $\begin{array}{c}\text { Index } \\
\mathbf{2 0 1 9 / 2 0 1 8}\end{array}$ \\
\hline Total income & $\begin{array}{c}436.181 .39 \\
5\end{array}$ & $\begin{array}{c}512.491 .68 \\
6\end{array}$ & $\begin{array}{c}380.564 .82 \\
8\end{array}$ & $117,50 \%$ & $74,26 \%$ \\
\hline $\begin{array}{c}\text { Total } \\
\text { expenditure }\end{array}$ & $\begin{array}{c}410.964 .57 \\
1\end{array}$ & $\begin{array}{c}485.982 .68 \\
6\end{array}$ & $\begin{array}{c}563.598 .48 \\
7\end{array}$ & $118,25 \%$ & $115,97 \%$ \\
\hline
\end{tabular}

Source: Carpatica Bank Data

Continuing the analysis, it is found that the dynamics of revenues is lower than the dynamics of expenditures in the horizon under analysis, which means that each additional leu spent leads to relative losses (see table 1). The situation can be considered unfavorable, as bank revenues increase in 2018 compared to 2017 by $17.50 \%$, but do not exceed the increase recorded by bank expenditures in the same period $(18.25 \%)$. While expenses outline an upward trend and increase in 2019 compared to 2018 by $15.97 \%$, revenues decrease significantly in value by $25.74 \%$.

The present situation raises the issue of the decrease of the activity volume of the banking unit, which also leads to the decrease of the profitability, due first of all to the accelerated increase of the bank expenses. At the same time, the degree of efficiency is called into question.

The decision to expand the activity was taken without establishing concrete directions of action and without following the dynamics of the various categories of expenditure (Stefănescu, 2013). The expansion of the activity is done only under the conditions of maintaining the level of profitability or improving it.

The problem of irrational consumption is thus taken into account and a detailed and comparative analysis of income and expenditure is needed to determine the causes that led to this situation and to take the right action to stabilize economic values.

\subsubsection{Analysis of the structure and dynamics of bank revenues}

A proposed example is that of the Carpathian Commercial Bank, where it is observed that the unit did not face natural disasters during the three financial years, so that the revenues are entirely revenues specific to a credit institution (see table 2).

Table 2. Analysis of bank income dynamics by categories.

\begin{tabular}{|c|c|c|c|c|c|}
\hline Elements & $\mathbf{2 0 1 7}$ & $\mathbf{2 0 1 8}$ & $\mathbf{2 0 1 9}$ & $\begin{array}{c}\text { Index } \\
\mathbf{2 0 1 8} / \mathbf{2 0 1 7}\end{array}$ & $\begin{array}{c}\text { Index } \\
\mathbf{2 0 1 9 / 2 0 1 8}\end{array}$ \\
\hline Interest income & $\begin{array}{c}281.568 .1 \\
87\end{array}$ & $\begin{array}{c}204.115 .3 \\
42\end{array}$ & 160.206 .372 & $72,49 \%$ & $78,39 \%$ \\
\hline $\begin{array}{c}\text { Commission } \\
\text { income }\end{array}$ & $\begin{array}{c}41.543 .34 \\
8\end{array}$ & $\begin{array}{c}34.188 .41 \\
1\end{array}$ & 30.199 .785 & $82,32 \%$ & $88,06 \%$ \\
\hline
\end{tabular}




\begin{tabular}{|c|c|c|c|c|c|}
\hline Financial income & $\begin{array}{c}92.311 .46 \\
4\end{array}$ & $\begin{array}{c}260.423 .7 \\
87\end{array}$ & $\begin{array}{c}176.783 .8 \\
41\end{array}$ & $282,15 \%$ & $67,85 \%$ \\
\hline $\begin{array}{c}\text { Operating } \\
\text { income }\end{array}$ & $\begin{array}{c}20.788 .49 \\
8\end{array}$ & $\begin{array}{c}13.866 .14 \\
6\end{array}$ & $\begin{array}{c}13.574 .83 \\
0\end{array}$ & $66,25 \%$ & $98,12 \%$ \\
\hline
\end{tabular}

Source: Carpatica Bank Data

Developing the analysis, it is found that bank interest income is on a downward trend, so that in 2018 compared to 2017 , bank interest income decreases by $27.51 \%$, and in 2019 decreases compared to 2018 by $21.51 \%$.

The situation is not favorable for the banking unit, as interest income is that which results from the current, repetitive activity of the bank. Regarding the share of this element in total revenues, it is observed that in 2017, bank interest income had a share of $64.55 \%$, in 2018 , the share decreased to $39.83 \%$, and in the last year of the analysis increased to $42.10 \%$.

Another observation that leads to the present situation is that the bank's lending activity decreased in intensity, leading to a decrease in profitability.

\subsubsection{Comparative evolution of financial performance}

Next, the evolution of the performance indicators, the economic profitability rate and the financial profitability rate were presented, by comparison, taking into account the values registered by the analyzed bank- Carpatica Comercial Bank, Transilvania Bank, Groupe Societé Generale and the Romanian banking system.

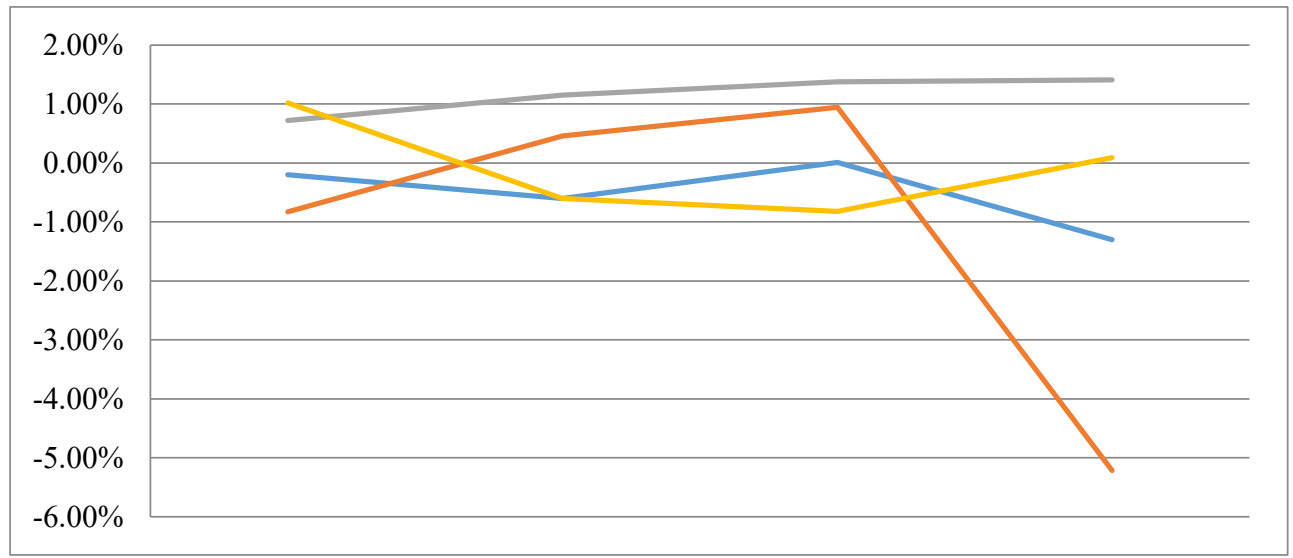

Figure 1. Comparative evolution of the economic profitability rate (2016-2019).

Source: Romanian banking system

The rate of economic profitability presents values higher than the level of the Romanian banking system at Banca Transilvania in the four financial years (see figure 1). The mentioned bank registers an increasing trend in terms of profit for the analyzed period. The economic profitability rate of Carpatica Bank shows higher values than the values recorded 
at the level of the banking system only in 2017, previously registering only lower values. Banks operate based on the criterion of profitability, aiming to obtain constant profit, with certain risks and in compliance with the Corporate Governance Code imposed by the Bucharest Stock Exchange, but also by the Corporate Governance Code developed by each bank. The rate of economic profitability has a positive evolution in the first three years of the analysis, but due to the loss recorded in 2019 , its value is negative $(-5.21 \%)$. The rate of financial profitability shows the same trend, being influenced by the same element as the

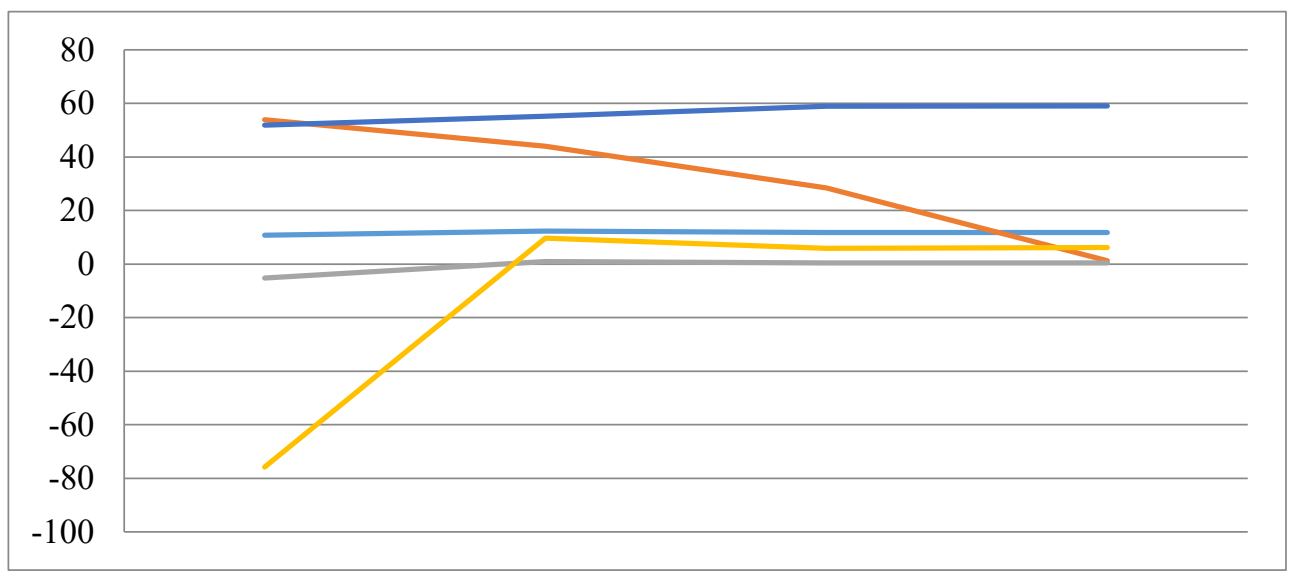

previous indicator, reaching up to $75.80 \%$ in 2019 .

Figure 2. The evolution of synthesis indicators (2016-2019).

Source: Romanian banking system

The Loans / Deposits ratio has a downward evolution in the analyzed years, reaching from $59.04 \%$ to $51.87 \%$. The value of the indicator calls into question the liquidity of the credit institution, so there is talk of a liquidity deficit, which means that the share of bank loans in total liabilities has increased.

As can be seen from the chart above (see figure 3), the solvency indicator does not show major changes, as does the Loans/Deposits ratio. Due to the loss of registration in 2019, profitability rates decrease to negative values.

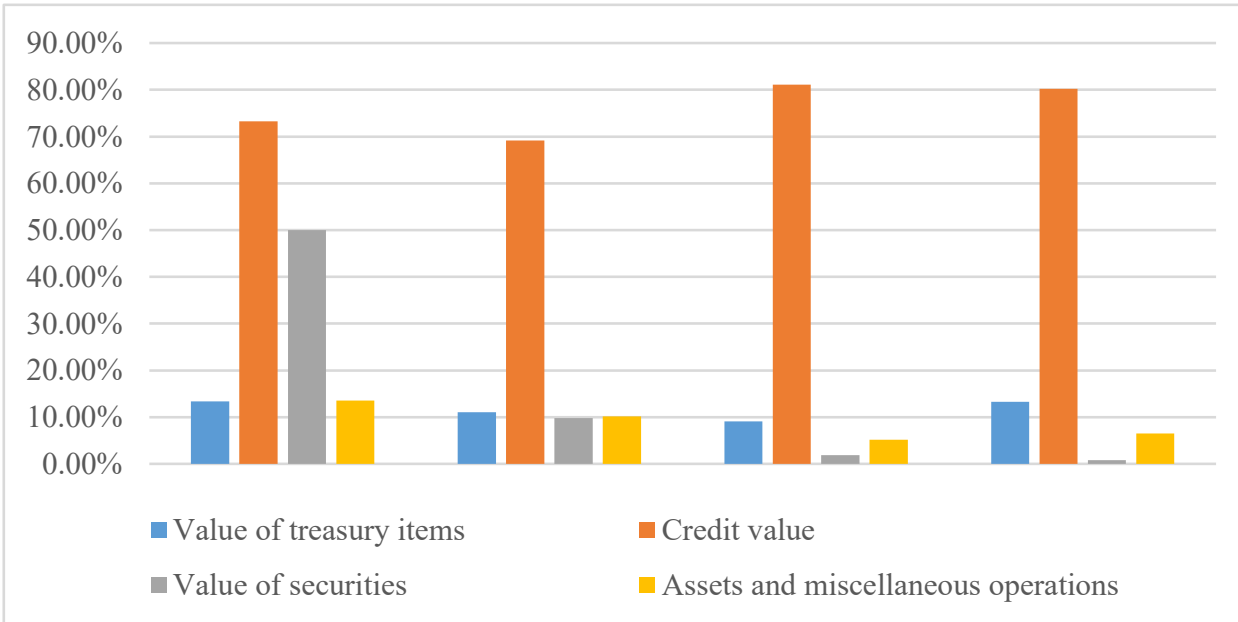


Figure 3. Balance sheet structure rates (2016-2019).

Source: Romanian banking system

The ratio between treasury items and total assets is considered beneficial if it is below the level of $25-30 \%$. It is observed that on the horizon subject to analysis, the rate falls within the mentioned percentage, which means that the credit institution manages its resources correctly, and the management pursues an investment policy. The money circuit leads to increased profitability.

The rate related to the amount of loans and total assets may not be less than $20 \%$. During the analyzed period, this rate records the largest shares in total assets. As a percentage, it is between $69.10 \%$ and $81.13 \%$, which means that the credit risk arises. The bank has a high risk exposure. The optimal level of this rate is $35-40 \%$.

The share of securities in total assets is reduced to zero in 2019 amid a less risky liquidity management strategy and leverage reduction. The situation is similar to that of the first year of the analysis. The tendency for the bank's management is to make the most of this area, which is very profitable and low risk.

As an evolution over time, the value of treasury items does not have a uniform trend. In 2017 , the value of treasury items decreased by $4.25 \%$, and in 2018 and 2019 will increase by $2.03 \%$ and $2.23 \%$, respectively.

Assets and miscellaneous operations decreased in 2017 compared to 2016 by $1.37 \%$. In the next two periods, it has a positive evolution increasing by $4.98 \%$ in 2018 compared to 2017 and by $3.35 \%$ in 2019 compared to 2018 . Miscellaneous operations and equity hold a share are $20 \%$, so respect the optimal level.

\section{Conclusion}

In conclusion, there are some difficulties faced by the banking unit, especially in the last year of the analysis. First, the analysis of bank revenues and expenditures shows that the dynamics of revenues is lower than the dynamics of expenditures. This situation is unfavorable and means that every RON spent leads to relative losses, ie it is irrational consumption. Thus, the bank's activity volume is decreasing, as well as its profitability, calling into question the degree of efficiency.

The data are the result of the extension decision, which was taken without establishing the directions of action and without following the dynamics of the various categories of expenditure. Although the dynamics of bank revenues exceed the dynamics of bank expenditures, behind the figures lies the reality of the economic environment. There are many more individuals or legal entities that use loans than there are deposits. Thus, the bank has to resort to external financing, which involves additional costs.

The number of asset rotations is an element that needs to be controlled and it is preferable to increase it from one period to another. In this case, the situation is not favorable and concrete ways of action to increase this element must be identified.

The unfavorable situation facing the banking unit is due to the decisions taken at the management level, both by the supervisory board and by the management. Also, the committees subordinated to each of them did not show efficiency in managing the problems faced by the banking unit.

\section{Acknowledgements}

Thanks to the team for their help in writing this article. I would like to thank the National Institute of Statistics and Banking analyzed for their assistance with the statistics used in this 
report. I would like to express my deep gratitude to my colleagues for their continued encouragement, critical analysis of this article, and guidance.

\section{References:}

1. Albu, N., Durica, A., Grigore, N., Grigoraș, D., Mateescu, R., \& Ichim, A. (2013). Guvernanța corporativă în Romania. Percepții și perspective. [Online]

2. Arniati, T., Puspita, D.A., Amin, A., \& Airzada, K. (2019). The implementation of good corporate governance model and auditor independence in earnings' quality improvement. Entrepreneurship and Sustainability Issues, 7(1), 188-200.

3. Arora, A, \& Bodhanwala, S. (2018). Relationship between corporate governance index and firm performance: Indian evidence. Global Business Review, 19(3), 675-689.

4. Bodislav, D. A., Burlacu, S., Rădulescu, C. V., \& Gombos, S. P. (2021). Using a hybid economic indicator (BADEM) to evaluate the retail sector (R5N) and consumption. 7th BASIQ International Conference on New Trends in Sustainable Business and Consumption. Foggia, Italy, 34-42.

5. Bunea, M. (2013). Impactul guvernanței corporative în creșterea performanței bancare. [Online]

6. Burlacu, S., Alpopi, C., Mitrită, M., \& Popescu, M. L. (2019). Sustainable e-governance and human resource development. European Journal of Sustainable Development, 8(5), $16-16$.

7. Catană R., \& Popa A. (2015). Guvernanța corporativă în sectorul bancar din România. [Online]

8. Chen, H. K., Liao, Y. C., Lin, C. Y., \& Yen, J. F. (2018). The effect of the political connections of government bank CEOs on bank performance during the financial crisis. Journal of Financial Stability, 36(c), 130-143.

9. Ciftci, I., Tatoglu, E., Wood, G., Demirbag, M., \& Zaim, S. (2019). Corporate governance and firm performance in emerging markets: evidence from Turkey. International Business Review, 28(1), 90-103.

10. Cornel, B. (2019). Dependent development at a crossroads? Romanian capitalism and its contradictions. West European politics, 42(5), 1041-1068.

11. Coșneanu, S., Russu C., Chirițescu V., \& Badea L. (2013). Necesitatea implementării guvernanței corporatiste în întreprinterile românești. [Online]

12. Dobroțeanu, C., Dobroțeanu, L., \& Răileanu, A. (2011). Auditul financiar în contextul reglementărilor privind guvernanța corporativă, Audit financiar, Editura Camera Auditorilor financiari din România, Anul IX, nr. 4/2011, 27.

13. Donnelly, S. (2018). Power politics, banking union and EMU: Adjusting Europe to Germany. London: Routledge.

14. E-Vahdati, S., Zulkifli, N., \& Zakaria, Z. (2019). Corporate governance integration with sustainability: A systematic literature review. Corporate Governance: The International Journal of Business in Society, 19(2), 255-269.

15. Haris, M., Hongxing, Y., Gulzara, T., Hafiz, M. J., \& Qurat, U. A. (2019). Corporate governance, political connections, and bank performance. International Journal of Financial Studies, 7(62), 1-37.

16. Ionita, F., Burlacu, S., \& Gaidargi, A. (2009). Modern approaches of the management of alternative trade systems. Review of International Comparative Management, 10(1), 473480 . 
17. Muhammad, H., Hongxing, Y., Gulzara, T., Hafiz Mustansar, J., \& Qurat Ui, A. (2019). Corporate governance, political connections, and bank performance. International Journal of Financial Studies, 7(4), 62.

18. Nastase, M., Roja, A., Burlacu, S., Coroban, L., Matis, C., Cristescu, I., \& Cristache, N. (2020). Perspectives regarding the organizational culture within the Romanian textile industry. Industria Textila, 71(1), 73-80.

19. Orzan, M. C., Burlacu, S., Florescu, M. S., Orzan, O. A., \& Macovei, O. I. (2020). The effects of online marketing on financial performance in the textile industry. Industria Textila, 71(3), 288-293.

20. Pham, Q., Ho, T., Pham, D., \& Nguyen, H. (2020). Effects of corporate governance on high growth rate: evidence from Vietnamese listed companies. Management Science Letters, 10(7), 1553-1566.

21. Profiroiu, A., Burlacu, S., \& Sabie, O. (2019). Reform of the pension system in Romania. Quality-Access to Success, 20(S2), 521-524.

22. Radulescu, C. V., Bran, F., Burlacu, S., Dobrea, C. R., \& Diaconu, S. (2020). Challenges regarding food resources in the context of globalization and population growth. Proceedings of the International Conference on Economics and Social Sciences, 10411052.

23. Sarbu, R., Alpopi, C., Burlacu, S., \& Diaconu, S. (2021). Sustainable urban development in the context of globalization and the health crisis caused by the covid-19 pandemic. SHS Web of Conferences, 92.

24. Stefănescu, C. (2013). Independență în guvernanța corporativă. Audit financiar, Editura Camera Auditorilor financiari din România, Anul XI, nr. 103 - 7/2013, 8.

25. Verdun, A., \& Zeitlin, J. (2018). Introduction: The European Semester as a new architecture of EU socioeconomic governance in theory and practice. Journal of European public policy, 25(2), 137-48. 